patients with Hodgkin's disease who had undergone splenectomy. Nevertheless, the normal pre-splenectomy concentrations are consistent with the fact that in Hodgkin's disease splenic function remains intact despite the attack on the reticuloendothelial system. ${ }^{17}$ Our results suggest that the practice of performing staging laparotomy and splenectomy in patients with Hodgkin's disease should be reconsidered. ${ }^{1 \times}$

Najiar et al determined the activity of tuftsin in serum by using the polymorphonuclear leucocyte-bacteria phagocytosis system, ${ }^{8}$ but this is an indirect qualitative assay requiring a large volume of blood and much time. Our radioimmunoassay can measure tuftsin qualitatively, only a little serum is needed, and the method is relatively simple. The assay is reproducible: results obtained from the same subjects on different days and different times of day showed a high degree of correlation $(\mathrm{r}=0.98)$.

It seems important that we should use our method to evaluate tuftsin concentrations in the familial tuftsin deficiency syndrome as well as in other hyposplenic states, such as congenital asplenia, ${ }^{19}$ coeliac disease, ${ }^{20}$ ulcerative colitis, ${ }^{21}$ splenic atrophy, ${ }^{19}$ splenic infarction, and premature birth. We are currently investigating a group of patients suffering from sickle-cell anaemia. ${ }^{22}$ The existence of a simple and reliable method for measuring tuftsin concentrations in human serum may perhaps be important in managing patients in hyposplenic states. The results may help to determine the necessity and optimum duration of prophylactic antibiotic treatment, and, as recently suggested, ${ }^{23}$ it may be worth while to consider the use of tuftsin as a drug.

\section{References}

1 Eraklis, A J, et al, New England fournal of Medicine, 2967, 276, 1225.

2 Smith, C H, et al, fournal of Diseases of Childhood, 1956, 92, 507.

${ }^{3}$ Bulfanz, J R, et al, Fournal of Pediatrics, 1976, 88, 458.

- Grinblat, J, and Gilboa, Y, American fournal of Medical Sciences, 1975, 270, 523.

5 Lancet, 1967, 1, 1167.

${ }^{6}$ Walter, W, British fournal of Surgery, 1976, 63, 36.

7 Constantopoulos, A, Najiar, V A, and Wish, J B, American fournal of Diseases of Children, 1973, 125, 663.

${ }^{8}$ Najjar, V A, and Nishioka, K, Nature, 1970, 228, 672.

${ }^{9}$ Najiar, V A, and Constantopoulos, A, Fournal of Reticuloendothelial Society, 1972, 12, 197.

${ }^{10}$ Nishioke, K A, et al, Biochemical and Biophysical Research Communications, $1972,47,172$.

${ }^{11}$ Fridkin, M, et al, Biochemica Biophysica Acta, 1977, 496, 203.

12 Spirer, Z, et al, fournal of Clinical Investigation, 1975, 55, 198

${ }^{13}$ Spirer, Z, et al, European fournal of Immunology, 1977, 7, 69.

${ }^{14}$ Donaldson, S S, et al, New England fournal of Medicine, 1972, 287, 69.

${ }^{15}$ Chilcote, R R, Baehner, R L, and Hammond, D, New England fournal of Medicine, 1977, 295, 798.

${ }_{16}$ Andersen, V, Cohn, J, and Sorensen, S F, Acta Pediatrica Scandinavica, $1976,65,409$.

17 Sheagran, J N, Block, J B, and Wolff, S M, Fournal of Clinical Investigation, 1967, 46, 855.

${ }^{18}$ British National Lymphoma Investigation, Clinical Radiology, 1975, 26, 151.

19 Waldman, J D, et al, fournal of Pediatrics, 1977, 90, 555.

${ }^{20}$ Wardrop, C A J, et al, Lancet, 1965, 2, 4.

${ }^{21}$ Ryan, F P, et al, Lancet, 1974, 2, 318.

22 Pearson, H A, Spencer, R P, and Cornelius, E A, New England fournal of Medicine, 1969, 281, 923.

${ }^{23}$ Mikulski, S M, et al, New England fournal of Medicine, 1977, 296, 454.

(Accepted 14 October 1977)

\title{
Comparison of metformin and chlorpropamide in non-obese, maturity-onset diabetics uncontrolled by diet
}

\author{
B F CLARKE, I W CAMPBELL
}

British Medical fournal, 1977, 2, 1576-1578

\section{Summary}

The clinical effectiveness of metformin was compared with that of chlorpropamide in closely similar groups of 216 non-obese patients recently diagnosed as cases of maturity-onset diabetes that could not be controlled by diet. The incidences of primary and secondary drug failures in each group and the numbers of patients satisfactorily maintained on each of the hypoglycaemic agents throughout the first year proved remarkably similar. In 61 of the successfully treated patients who were studied by crossover to the other drug and observed for a further year the mean blood glucose concentrations at the end of the year were roughly comparable, but the mean weight response was a small loss of $1.5 \pm 3.8 \mathrm{~kg}$ with metformin but a gain of $4.6 \pm 3.9 \mathrm{~kg}$ with chlorpropamide.

Thus for non-obese, maturity-onset diabetics whose disease cannot be controlled by diet and who require oral treatment sulphonylureas and biguanides are equally effective, the choice depending on whether the patient is underweight and the severity of symptoms.

\footnotetext{
Diabetic and Dietetic Department, Royal Infirmary, Edinburgh EH3 9YW

B F CLARKE, FRCP, consultant physician and senior lecturer

I W CAMPBELL, MRCP, senior registrar
}

\begin{abstract}
Introduction
Since sulphonylureas became available before biguanides and have fewer side effects they have tended to become the treatment of choice in maturity-onset diabetes that cannot be controlled by diet. Few controlled studies have therefore been carried out to compare the clinical effectiveness of sulphonylureas and biguanides, particularly metformin, in this condition. The present study was designed specifically to compare the clinical responses to metformin and chlorpropamide in non-obese, maturity-onset diabetics uncontrolled by diet.
\end{abstract}

\section{Patients and methods}

Patients considered for inclusion in the study were aged 40-79 years and had been diagnosed as diabetic less than three months previously. None was ketotic or obese (body weights below $109 \%$ (below $100 \%$ in most cases) of standard weight), and none had already received an oral hypoglycaemic agent or insulin. Patients regarded as diet failures included: (a) true diet failures-namely, patients who despite adherence to diet for at least four weeks had a two-hour postprandial blood glucose concentration exceeding $14.0 \mathrm{mmol} / \mathrm{l}$ $(252 \mathrm{mg} / 100 \mathrm{ml})$, often with persisting symptoms and very little weight gain; and $(b)$ predicted diet failures-namely, patients for whom a trial on diet alone was not believed to be justified because of severe thirst and polyuria, loss of weight, and initial blood glucose concentrations exceeding $14.0 \mathrm{mmol} / \mathrm{l}$, and often much higher. Patients known to have severe disease such as congestive cardiac failure or neoplasia were excluded from the study, as were patients who had been receiving diabetogenic drugs.

Two hundred and nineteen patients ( 86 men and 133 women) 
satisfied the criteria for inclusion and were allocated consecutively to treatment with either metformin (Glucophage) or chlorpropamide (Diabinese). Three patients were excluded shortly after the study began because of the discovery of neoplastic disease in two and the development of severe cardiac failure in one. The results in the remaining 216 patients were examined in two age subgroups, 40-59 years and $60-79$ years. The initial ages, body weights, and blood glucose concentrations in the metformin and chlorpropamide subgroups were highly comparable (table I). The initial dose of metformin of $0.5 \mathrm{~g}$ twice daily was increased by $0.5 \mathrm{~g}$ every one or two weeks if necessary to a maximum of $3.0 \mathrm{~g}$ daily. Chlorpropamide was given in an initial dose of $100-375 \mathrm{mg}$ daily, which was increased if necessary to a maximum of $375 \mathrm{mg}$ given as a single daily dose. Blood glucose concentrations were measured in capillary blood taken two to three hours after breakfast, an AutoAnalyzer and a glucose oxidase method being used. The patients generally attended the outpatient clinic at intervals of one to three months, but more often if treatment was inadequate. For the purposes of the study, failure of control was arbitrarily defined as a blood glucose concentration consistently above $14.0 \mathrm{mmol} / 1(252 \mathrm{mg} / 100 \mathrm{ml})$, which was usually associated with symptoms.

Patients were observed during the first year to establish both the incidences of true primary and secondary drug failures and the numbers still successfully controlled on the original agent. At the end of the first year 61 patients who had been satisfactorily maintained on the original agent (37 on metformin and 24 on chlorpropamide) served as their own controls in a crossover study. After a period on diet alone, when their condition deteriorated to about the same degree as it had been initially, they changed to the other agent for a further year and their blood glucose and body weight responses were compared. Standard statistical methods were used for analysis, and the results are expressed as means \pm SD.

\section{Results}

Twenty-seven patients failed to complete the first year of study because of default (six patients); death (nine; three receiving metformin and six chlorpropamide); intercurrent illness (four); side effects from metformin (three); and subsequent satisfactory control by die alone (five). The outcome in the remaining 189 patients at the end of the first year is shown in table II. There was no significant difference between the two agents in the incidences of primary and secondary drug failures or in the numbers of patients being maintained on the original agent. In these patients the blood glucose concentrations were similar with both drugs but there was a significant difference in body weight responses. The younger age group lost a mean of $2.1 \pm 3.9 \mathrm{~kg}$ with metformin but gained $3.6+5.0 \mathrm{~kg}$ with chlorpropamide $(\mathbf{P}<0.001)$. A similar difference was found in the older group $(\mathrm{P}<0.001)$. At the end of the first year the drug dosage in the 81 patients receiving metformin was $2 \cdot 0 \pm 0.6 \mathrm{~g}$ (range $1 \cdot 0-3 \cdot 0 \mathrm{~g}$ ), and in the 75 patients taking chlorpropamide the dosage was $284 \pm 95 \mathrm{mg}$ (range 100-375 mg). Metformin doses of 3.0 and $2.5 \mathrm{~g}$ daily were required by only eight $(9.9 \%)$ and $16(19.8 \%)$ patients respectively, whereas 32 patients $(42.7 \%)$ required a chlorpropamide dose of $375 \mathrm{mg}$ daily. Twenty-six patients $(24.3 \%)$ experienced transient and usually mild gastrointestinal symptoms with metformin, but three $(2.8 \%)$ had to stop the drug because of persistent side effects. Lacticacidosis was not observed in any patient taking metformin. Adverse effects with chlorpropamide consisted of only transient gastrointestinal symptoms (one patient), transient rash (one), and mild hypoglycaemia (one).

Of the 61 patients included in the crossover study, all but one with primary failure on chlorpropamide and two with secondary failures on metformin completed the further year on the other drug. The mean blood glucose concentration at the end of the year in these 58 patients was $8.9 \pm 1.9 \mathrm{mmol} / 1(160 \pm 34 \mathrm{mg} / 100 \mathrm{ml}$ ) (range $4.3-13.3 \mathrm{mmol} / \mathrm{l}$; $77-239 \mathrm{mg} / 100 \mathrm{ml}$ ) with metformin and $7 \cdot 8 \pm 2 \cdot 0 \mathrm{mmol} / 1(140 \pm$ $36 \mathrm{mg} / 100 \mathrm{ml}$ ) (range $3.3-12.8 \mathrm{mmol} / 1 ; 59-230 \mathrm{mg} / 100 \mathrm{ml}$ ) with chlorpropamide $(P<0.005)$. There was a mean loss of $1.5 \pm 3.8 \mathrm{~kg}$ (range -9.5 to $+5.9 \mathrm{~kg}$ ) with metformin and a mean gain of $4.6 \pm 3.9$ $\mathrm{kg}$ (range -7.7 to $+15.0 \mathrm{~kg}$ ) with chlorpropamide $(\mathrm{P}<0.001)$. These significant differences occurred irrespective of the sequence of treatment.

\section{Discussion}

Biguanides, although well established in the treatment of maturity-onset diabetes, have been used mainly as additional treatment in cases that cannot be controlled with sulphonylureas $^{1-3}$ and in obese patients with uncontrolled diabetes who would gain more weight if treated with a sulphonylurea. ${ }^{4}$ In this study of non-obese, maturity-onset diabetics whose disease could not be controlled by diet alone metformin was compared with chlorpropamide, which is still probably the most potent sulphonylurea available and as effective as the recently introduced second-generation group. ${ }^{5}$ Despite the wide differences in pharmacology and mode of action of each agent, the clinical effectiveness of metformin was shown to be remarkably similar to that of chlorpropamide. The body-weight responses to the two drugs were significantly different, however, for there was a slight mean loss in patients who received metformin and a gain in most of those who received chlorpropamide. These changes were similar to those that occur in obese patients with uncontrolled diabetes treated with the same drugs. ${ }^{4}$

The choice of an oral agent for maturity-onset diabeticsespecially those with symptoms-who have more severe hyperglycaemia and in whom diet has failed is usually limited to one of the sulphonylureas, which may be given initially in maximum

TABLE I-Details of 216 patients in treatment subgroups (mean values expressed $\pm S D$ )

\begin{tabular}{|c|c|c|c|c|c|c|c|c|}
\hline \multirow{2}{*}{$\underset{(\text { years })}{\text { Age }}$} & \multirow{2}{*}{$\begin{array}{l}\text { Treatment } \\
\text { subgroup }\end{array}$} & \multirow{2}{*}{$\begin{array}{c}\text { No of } \\
\text { patients }\end{array}$} & \multicolumn{2}{|c|}{ Sex } & \multirow{2}{*}{$\begin{array}{l}\text { Initial age } \\
\text { in years } \\
\text { (range) }\end{array}$} & \multirow{2}{*}{$\begin{array}{l}\text { Initial weight, } \\
\text { as } \% \text { of SW } \\
\text { (range) }\end{array}$} & \multirow{2}{*}{$\begin{array}{l}\text { Initial blood glucose } \\
\text { concentration, in } \\
\text { mmol/ (range) }\end{array}$} & \multirow{2}{*}{$\begin{array}{l}\text { Initial drug } \\
\text { dose/day } \\
\text { (range) }\end{array}$} \\
\hline & & & $\mathrm{M}$ & $\bar{F}$ & & & & \\
\hline $\begin{array}{l}40-59 \\
60-79\end{array}$ & $\begin{array}{l}\text { Chlorpropamide } \\
\text { Metformin } \\
\text { Chlorpropamide } \\
\text { Metformin }\end{array}$ & $\begin{array}{l}44 \\
45 \\
65 \\
62\end{array}$ & $\begin{array}{l}17 \\
19 \\
28 \\
21\end{array}$ & $\begin{array}{l}27 \\
26 \\
37 \\
41\end{array}$ & $\begin{array}{l}52 \cdot 3=4 \cdot 9(40-59) \\
53 \cdot 8=4 \cdot 6(40-59) \\
67 \cdot 6=5 \cdot 2(60-77) \\
66 \cdot 2=4 \cdot 8(60-77)\end{array}$ & $\begin{array}{l}95 \cdot 7: 9 \cdot 9(71-109) \\
95 \cdot 6: 7 \cdot 9(72-109) \\
91 \cdot 1: 9 \cdot 1(72-107) \\
93 \cdot 5: 6.9(75-108)\end{array}$ & $\begin{array}{l}17 \cdot 3+3 \cdot 0(14 \cdot 0-26 \cdot 9) \\
17 \cdot 7+2 \cdot 9(14 \cdot 4-25 \cdot 5) \\
17 \cdot 4=3 \cdot 3(14 \cdot 4-28 \cdot 6) \\
17 \cdot 5 \div 2 \cdot 4(14 \cdot 4-23 \cdot 3)\end{array}$ & $\begin{array}{c}269 \pm 61(100-375) \mathrm{mg} \\
1.0 \mathrm{~g} \\
254 \pm 61(100-375) \mathrm{mg} \\
1.0 \mathrm{~g}\end{array}$ \\
\hline
\end{tabular}

SW $=$ Standard weight.

Conversion: SI to traditional units-Glucose: $1 \mathrm{mmol} 1=18 \mathrm{mg} 100 \mathrm{ml}$.

TABLE II-Results of treatment in 189 patients completing first year with original agent (means $\pm S D$ )

\begin{tabular}{|c|c|c|c|c|c|c|c|c|c|c|}
\hline \multirow[b]{2}{*}{$\begin{array}{c}\text { Age } \\
\text { (years) }\end{array}$} & \multirow[b]{2}{*}{$\begin{array}{l}\text { Treatment } \\
\text { subgroup }\end{array}$} & \multirow[b]{2}{*}{$\begin{array}{l}\text { No of } \\
\text { patients }\end{array}$} & \multicolumn{4}{|c|}{ Successful control } & \multicolumn{2}{|c|}{ Primary failure } & \multicolumn{2}{|c|}{ Secondary failure } \\
\hline & & & No & $" 0$ & $\begin{array}{l}\text { Final blood glucose } \\
\text { concentrations, in } \\
\text { mmol 1 (range) }\end{array}$ & $\begin{array}{l}\text { Weight change, in kg } \\
\text { (range) }\end{array}$ & No & ${ }_{0}$ & No & $0_{0}$ \\
\hline $\begin{array}{l}40-59 \\
60-79\end{array}$ & $\begin{array}{l}\text { Chlorpropamide } \\
\text { Metformin } \\
\text { Chlorpropamide } \\
\text { Metformin }\end{array}$ & $\begin{array}{l}38 \\
39 \\
53 \\
59\end{array}$ & $\begin{array}{l}31 \\
32 \\
44 \\
49\end{array}$ & $\begin{array}{l}81 \cdot 6 \\
82 \cdot 1 \\
83 \cdot 0 \\
83 \cdot 0\end{array}$ & $\begin{array}{l}8 \cdot 4: 1 \cdot 7(5 \cdot 4-11 \cdot 1)^{*} \\
8 \cdot 8=1 \cdot 5(5 \cdot 3-11 \cdot 3) \\
8 \cdot 5=2 \cdot 2(3 \cdot 3-13 \cdot 3)^{*} \\
8 \cdot 9 \pm 1 \cdot 4(5 \cdot 2-12 \cdot 1)\end{array}$ & $\begin{array}{l}+3.6: 5.0(-5.9 \text { to }+13 \cdot 6)+ \\
-2 \cdot 1 \cdot 3.9(-10 \cdot 0 \text { to }+5.9) \\
+2.9=3.8(-7.7 \text { to }+13 \cdot 2)+ \\
0.0=3.3(-7.7 \text { to }+5.9)\end{array}$ & $\begin{array}{l}4 \\
5 \\
5 \\
7\end{array}$ & $\begin{array}{r}10 \cdot 5 \\
12 \cdot 8 \\
9.5 \\
11.9\end{array}$ & $\begin{array}{l}3 \\
2 \\
4 \\
3\end{array}$ & $\begin{array}{l}7 \cdot 9 \\
5 \cdot 1 \\
7 \cdot 5 \\
5 \cdot 1\end{array}$ \\
\hline
\end{tabular}


dosage and provides rapid relief. The disadvantage of biguanides is their gastrointestinal side effects, which marred the assessment of earlier clinical trials. If, however, as in this study, a small initial dose is given irrespective of the degree of hyperglycaemia and increased gradually, the side effects are usually mild and transient, and the drug has to be discontinued in only a few, possibly susceptible, patients. The earlier view that the use of biguanides was limited by their side effects therefore seems unjustified. Unlike treatment with the sulphonylureas, treatment with biguanides in therapeutic dosage is not associated with the risk of hypoglycaemia and there is virtual freedom from toxic and hypersensitivity effects.

Treatment with phenformin has been increasingly associated with severe lacticacidosis, especially in the presence of liver or kidney disease, circulatory failure, or other conditions promoting hypoxia, but lacticacidosis may occur in the absence of any of these factors. ${ }^{6}$ Phenformin given in therapeutic doses increases the blood lactate concentration to about $2 \mathrm{mmol} / 1(18.0 \mathrm{mg} / 100$ $\mathrm{ml}),{ }^{i}{ }^{8}$ which under normal circumstances is probably not clinically important. A recent comparative study showed that the rises in concentrations of blood lactate and other glyconeogenic precursors were greater with phenformin than with metformin. It was concluded that these metabolic changes could be accounted for by an inhibitory effect on hepatic glyconeogenesis and were therefore directly related to the lowering action of the biguanides on the blood glucose concentration. The plasma lactate concentration remained normal during glibenclamide treatment, but the serum insulin concentration was higher with the sulphonylurea than with the biguanides. ${ }^{9}$

Metformin, which has been used extensively in Britain and other European countries, is rarely associated with lacticacidosis, possibly because of its different pharmacokinetic properties. When lacticacidosis has occurred there has usually been coexistent renal failure, ${ }^{10}$ and the use of metformin should be avoided not only in this condition but probably also when there is mild renal impairment.

The findings of the University Group Diabetes Program (UGDP) in respect of increased cardiovascular risks with tolbutamide $^{11}$ and phenformin, ${ }^{12}$ although the subject of considerable criticism on the grounds of study design ${ }^{13}$ and analysis, ${ }^{14}$ are nevertheless disturbing. Most of the patients recruited were only mildly hyperglycaemic, asymptomatic, and obese with an average body weight of $130^{\prime}$ " correct weight. They were given fixed doses of the oral agents and would usually have been treated by diet alone in Britain. A statement by a "Task force on Phenformin" group from the American Diabetic Association conceded that in more severe cases of maturity-onset diabetes in which diet was unsuccessful and insulin was either refused or could not be used the use of oral agents could be neither promoted nor discouraged by the UGDP study. ${ }^{12}$

Our results indicate that in non-obese, maturity-onset diabetics whose disease cannot be controlled by diet and who require oral treatment, sulphonylureas and biguanides are equally effective. The choice of agent depends on the degree to which the patient is under weight and the severity of symptoms. If these are pronounced, a sulphonylurea is indicated. If the patient is near correct weight, however, particularly if he is apt to gain weight or if there is a risk of hypoglycaemia or hypersensitivity, then biguanide treatment with metformin might be preferable.

We thank Dr Leslie Duncan for encouragement, and Mrs Sadie Dickson and the staff of the diabetic and dietetic department, Royal Infirmary, for their help.

Requests for reprints should be addressed to Dr B F Clarke.

\author{
References \\ ${ }^{1}$ Mehnert, H, and Seitz, W, Münchener medizinische Wochenschrift, 1958, \\ $100,1849$. \\ 2 Bloom, A, et al, Postgraduate Medical fournal, 1964, 40, 654. \\ 3 Clarke, B F, and Duncan, L J P, Lancet, 1965, 1, 1248. \\ 4 Clarke, B F, and Duncan, L J P, Lancet, 1968, 1, 123. \\ 5 Clarke, B F, and Campbell, I W, Lancet, 1975, 1, 246. \\ 6 Fulop, M, and Hoberman, H D, Diabetes, 1976, 25, 292. \\ : Craig, J W, et al, Diabetes, 1960, 9, 186. \\ ${ }^{8}$ Varma, S K, et al, British Medical fournal, 1972, 1, 205. \\ ${ }^{9}$ Nattrass, M, et al, Diabetologia, 1977, 13, 145. \\ 11 Assan, R, et al, Diabetologia, 1977, 13, 211. \\ 11 University Group Diabetes Program, Diabetes, 1970, 19, suppl No 2, p 747. \\ 1.2 University Group Diabetes Program, Diabetes, 1975, 24, suppl No 1, p 65. \\ ${ }^{13}$ Seltzer, H S, Diabetes, 1972, 21, 976. \\ ${ }^{14}$ Schor, S S, American fournal of Medicine, 1973, 55, 727.
}

\title{
New classification of stroke: preliminary communication
}

\author{
R CAPILDEO, S HABERMAN， F CLIFFORD ROSE
}

British Medical fournal, 1977, 2, 1578-1580

\section{Summary}

We describe a new method of classifying stroke using a cumulative numbering system. The method is simple and more explicit than currently used classifications, and could be useful for different agencies looking after patients with stroke in hospital or at home.

\footnotetext{
Department of Neurology, Charing Cross Hospital (Fulham), London W6 8RF

$\mathrm{R}$ CAPILDEO, MB, MRCP, senior registrar in neurology

F CLIFFORD ROSE, FRCP, consultant neurologist

Department of Social Science and Humanities, City University, London EC1

S HABERMAN, MA, FIA, lecturer in actuarial science
}

\section{Introduction}

There is no universally accepted definition or classification of stroke. This is surprising, since stroke is the third commonest cause of death in the Western world and the single most important cause of disability. We describe here a new classification and terminology for defining stroke. We shall present a full discussion of definitions and classifications previously used with a detailed analysis of the new classification in a subsequent paper.

\section{Terminology}

A stroke is defined as "an acute disturbance of cerebral function of vascular origin causing disability lasting more than, or death within, 24 hours." This definition differs nowadays from that suggested in the report published in July 1974 by a working group of the Royal College of Physicians." Firstly, "vascular origin" replaces the term "presumed vascular origin." Unless the vascular origin has been established by appropriate investigation, the term "presumed stroke" 